\title{
Reflexionar la dictadura argentina y el Holocausto desde la literatura
}

\author{
Sabrina Zehnder ${ }^{\bullet}$ \\ Universität St. Gallen, Suiza
}

\section{Resumen}

Mi tesis doctoral Poética espacial de la diáspora y del exilio en la Trilogía de la memoria de Pedro Orgambide reflexiona la dimensión judía que componen las tres novelas. La investigación fue realizada en Alemania, lugar donde resido. Esta situación de alejamiento geográfico favoreció la configuración de una mirada vinculante entre el espacio judeoargentino y la historia judía en Alemania. En efecto, la judeidad, con sus múltiples rostros y características - lingüísticos, históricos y culturales - se devela, a pesar de sus diferentes recorridos, como un espacio con lugares compartidos.

El presente artículo explora los temas y motivos presentes en la Trilogía de la memoria del autor argentino que aluden a los hechos de persecución, antisemitismo y al genocidio judío ocurridos en Alemania en tiempos del nazismo. Analiza, además, situaciones y presencias que refieren a la dolorosa experiencia de la dictadura militar argentina (1976-1983), donde la represión y desaparición de personas de origen judío (y no judío), recuerdan los hechos del Holocausto alemán, subrayando la continuidad del genocidio y dando cuenta de los paralelismos entre ambos sistemas.

Esta reflexión se mueve dentro del marco del posnazismo y de la posdictadura argentina y pretende ser una muestra o visualización de lo literario e investigativo, pero también de miradas que surgen a partir de algunas experiencias personales.

\section{Palabras clave:}

- dimensión judía · dictadura militar argentina · nazismo . antisemitismo $\cdot$ Holocausto $\cdot$ Alemania

- Dr. phil. Sabrina Zehnder, MA en Literatura Alemana y Literatura de Habla Hispana (Universidad de Konstanz). Docente de la Universidad de Konstanz, Alemania, en el período 2014/2015. Desde 2014 es Docente encargada (Lecturer) en la Sección Idioma Español y Literatura en la Universidad de St. Gallen, Suiza. Su reciente publicación es un estudio, en alemán, de la película de Daniel Burman El abrazo partido (2004): Humor judío y sueños de migración para salir de la crisis" (Editorial Springer). Temas y campos de investigación: Literatura y Cultura argentina de los siglos XX y XXI, cine y humor judío, nomadismo y espacios. 


\begin{abstract}
My thesis for the PhD Poética espacial de la diáspora y del exilio en la Trilogía de la memoria de Pedro Orgambide considers the Jewish dimension composed in the three novels. The investigation took place in Germany, where I presently live. The fact of being distanced helped me to configure a binding point of view between the Argentinian-Jewish space and the Jewish history in Germany.

In fact, Jewishness, with its multiple faces and characteristics - linguistic, historical and cultural — is shown, despite their different wandering, like a shared space.

This article explores the topics and causes shown in the Trilogía de la memoria (Trilogy Of The Memory), from the Argentinian author, which referred to the persecution, antiSemitism and genocide to the Jewish people in Germany during Nazism. It also analyzes situations and presences that refer to the painful experiences of the militar dictatorship in Argentina (1976-1983), when the repression and disappearance of the Jewish people (and non Jewish), reminds us of German Holocaust, emphasizing the continuity of the genocide and showing a parallelism between both systems.

This reflection is exposed along the post Nazism and the post dictatorship in Argentina, and intends to be a sample or a display of the literature and investigation, but also of the glances that come up from some personal experiences.
\end{abstract}

\title{
Key words:
}

- jewish dimension ' dictatorship Argentina $\cdot$ nazism · antisemitism · Holocaust · Germany

\section{Reflexión como relato}

La idea que motivó este artículo surgió durante la etapa de mi investigación doctoral realizada en la Universidad de Konstanz, Alemania, donde el diálogo entre el espacio del dolor argentino se abría hacia el pasado del Holocausto. Hay que reconocer, sin embargo, que el estudio de las influencias y los puntos de contacto entre el nacionalsocialismo y la dictadura militar (1976-1983) fueron investigados ${ }^{1} y$ analizados $^{2}$ en trabajos científicos, representado en producciones fílmicas ${ }^{3}$ y documentales y ficcionalizados en relatos y testimonios. No se trata aquí de equiparar la Dictadura argentina con el Holocausto sino de abrir otros espacios que permitan reflexionar el «caso argentino» en un contexto amplio y actual. Nuestro propósito apunta a focalizar el vínculo existente entre la dictadura y el Holocausto ${ }^{4}$ en el caso concreto de la Trilogía de Pedro Orgambide, a partir de la presencia de motivos de la historia judía que, sin ser estereotipos 
o «trillados motivos de carácter universal« (Karduner, 1934:146), articulan simultáneamente las particularidades de carácter nacional y a su vez europeo/alemán. El artículo intenta ser un aporte al corpus de memoria que cabalga entre dos continentes. Comenzaremos con la etapa de surgimiento, elaboración y puntos centrales de la tesis como generador del artículo, para continuar con el análisis de algunos elementos, motivos e imágenes centrales presentes en las novelas y su relación con la Alemania nazi. Llegando al final, ofreceremos un hecho desde la «simple cotidianeidad» y actualidad para interpretar su mensaje.

\section{Poética espacial de la diáspora y del exilio en la Trilogía de la memoria ${ }^{5}$ de Pedro Orgambide}

Mi trabajo doctoral indaga la dimensión judía de la Trilogía de la Memoria del autor argentino Pedro Orgambide que componen las novelas El Arrabal del mundo (1984), Hacer la América (1984) y Pura memoria (1985). Tematiza los espacios de pertenencia de la comunidad judía en la cultura argentina a partir de principios del siglo XIX, indagando sus espacios lingüísticos, sociales y culturales. En un contexto más amplio, explica los espacios históricos como la diáspora, el exilio y la errancia. En cuanto a la inestabilidad y fragilidad espacial, le sigue las huellas al «violinista en el tejado» como una metáfora y un componente de la historia judía que encarna el equilibrio entre dos «superficies»: dos tradiciones, continentes u orígenes. Indaga, en particular, los procesos personales y grupales de los primeros migrantes judíos, que llegaron al país a finales del siglo XVIII, y la integración de sus hijos. Un punto referencial conforma el sueño de "hacer(se) la América» como sinónimo de seguridad y bienestar económico, movimiento que se repetirá casi 100 años más tarde y en dirección inversa, a causa de la gran crisis económica originada en Argentina. La propuesta examina, además, las distintas formas de lo judeoargentino, más allá de su existencia como temática que se alimenta, la mayoría de las veces, del recuerdo, de festividades, de la renovación de rituales y de viejos conflictos y se convierte, de esta manera, en una literatura estática y costumbrista, congelada en el tiempo. Lo judeoargentino supone, en este trabajo, un espacio asociado a recorridos inestables con cruces y retornos.

Escribir sobre la dimensión judía de un autor argentino significó poner en un primer plano cuestiones directamente referidas a las novelas que componen la Trilogía. Paralelamente, el tema se abrió hacia la historia y al destino judío en Europa occidental y oriental, donde Alemania centraliza las miradas en torno a temas ineludibles como los progomes, la formación de guettos, los campos de concentración y exterminio, la persecución y el Holocausto (1939-1945). No obstante, abundantes acontecimientos de violencia y prácticas represivas, desapariciones, torturas, persecución política y antisemitismo, son compartidos con la Dictadura argentina. 


\section{Motivos y presencias de la Trilogía que evocan el Holocausto alemán}

Escribir sobre la dimensión judía de la Trilogía significó indagar la historia argentina migrante a partir de 1880, donde se ubica temporalmente Hacer la América, segunda novela de la serie. Los protagonistas son migrantes italianos, españoles, alemanes y judíos rusos que buscan en Argentina un mejor porvenir. En el caso del colectivo judío, que se estructura en torno a la familia Burtfichtz, el señor Katz y David Silverstein, supone ir al encuentro de lugares sensibles y motivos que visibilizan del horror.

\section{El guetto}

Aboquémonos, por lo tanto, a focalizar algunas situaciones vividas por los Burtfichtz. La familia, compuesta por David, Raquel y Liuba escapa de Rusia y llega a Argentina, tierra que promete paz a los judíos del mundo. Después de un largo viaje en barco arriban a Buenos Aires para seguir camino a una colonia de inmigrantes en la provincia de Entre Ríos. Años más tarde volverán a un barrio judío de la capital, probablemente Once, que no remedará su antiguo pueblo ruso ni tampoco será la Tierra Prometida. «Los Burtfichtz alquilaron pieza. El barrio, barrio de judíos, reproducía en menor escala las costumbres del ghetto» (HA 155), informa el narrador, introduciendo el término guetto, uno de los lugares más desesperanzados de la historia judía contemporánea. Según la explicación de Loic Wacquant guetto fue

Acuñado por derivación de los vocablos italianos giudeca, borghetto o gietto (o del alemán Gitter o el hebreo talmúdico get: la etimología se sigue discutiendo), la palabra "guetto" se refiere inicialmente al confinamiento forzoso de los judíos a zonas especiales realizado por las autoridades políticas y religiosas de las ciudades. (Wacquant, 2010:121)

Sus elementos constitutivos son la «estigmatización, la presión, el confinamiento espacial y el enclaustramiento institucional» (123) y su desarrollo e historia están profundamente relacionados a la experiencia judía. Viktor Karady ${ }^{6}$ hace hincapie en la doble dimensión del guetto: por un lado el aislamiento degradante, por el otro, la protección contra los posibles peligros. Destaca, además, el lugar central de los centros urbanizados por causas económicas, políticas y de seguridad. Aunque guetto se relaciona en el imaginario colectivo con lugares de extremo padecimiento y pobreza en la ficción no representa un lugar de confinamiento. De hecho, en el período de la narración, a principios del siglo XX, el motivo del guetto anticipa un futuro próximo pero todavía lejano y en otras latitudes. Sin embargo, el narrador, reconociendo su implicancia en la historia de la comunidad judía, integra el término sin tratarlo directamente pero sin evitarlo. El «barrio de judíos» porteño «reproducía en menor escala las costumbres del guetto» hace memoria, tal como lo propone, de la organización y condiciones de vida en los shtetl, ${ }^{7}$ pequeños 
pueblos o barrios donde vivía la población judía en el este de Europa, sin llegar a ser un guetto. En Hacer la América, guetto constituye un lugar de prosperidad e intercambio de grupos minoritarios operando como un enclave étnico integrativo dentro de la sociedad de acogida:

Las cocinas olían a Rusia y Polonia y las calles se poblaban de vendedores ambulantes, talabarteros, mecánicos, chicos que masticaban sus semillas de girasol, viejos levitones y sombreros negros que marchaban a la sinagoga. (HA 155)

En Buenos Aires no hubo guettos sino «vecindarios, conglomerados étnicos o vecindarios de inmigrantes ${ }^{8}$ que albergaban a los recién llegados. Todas las comunidades buscaban su sitio en la ciudad, distribuyéndose según afinidades, evitando viejas rivalidades o por la relación de amistad o vínculos familiares con algún habitante del lugar. ${ }^{9}$ A pesar del sentido positivo con el que es utilizado el término, su presencia provoca y obliga a hacer un alto en la lectura. La convivencia barrio-guetto confunde y demanda una participación activa del lector: el concepto de barrio invita a la integración social armoniosa por el contrario, guetto, nos acerca a una imagen radicalmente opuesta. Este cruce de espacios encontrados origina una tensión, que le da protagonismo al pasado de la comunidad desde la ficción.

La caracterización de guetto que aporta Wacquant es a la que nos vamos a referir ahora por su relación con el nazismo y porque representa la contracara de la propuesta narrativa.

el encapsulamiento etnorracial puede llegar al punto en el que el gueto sirva como aparato para almacenar al grupo arruinado o prepararlo para la forma final de ostracismo, esto es, la aniquilación física. (Este) (...) escenario es el instrumentado en la Alemania nazi que revivió el Judenghetto entre 1939 y 1944, primero para empobrecer y concentrar a los judíos (...) y luego, (...) para empujarlos hacia los campos de exterminio. (Wacquant, 2010:138)

El término implica, en el contexto alemán, muerte, hacinamiento, exclusión y hambre y es la antesala del campo de exterminio. Su imaginario se articula en torno a dos ciudades muy reales y concretas elegidas para el confinamiento espacial. Lotz y Varsovia, ambas en Polonia, fueron muy tristemente conocidos como los lugares donde emplazaron los mayores centros para el confinamiento y deportación de judíos. ¿Por qué en Polonia? Porque era el país con mayor población judía de Europa y porque su ubicación, fuera del propio territorio, aseguraba que el plan de exterminio se mantuviera en secreto.

el 19 de septiembre de 1939 Hitler decidi(ó) incorporar oficialmente gran parte de Polonia a Alemania, trasladar a seiscientos mil judíos que estaban en esa zona a un resto de territorio polaco (...) y encerrar a todos los judíos que residían allí en lugares apropiados a lo largo de las líneas ferroviarias. Para concretar el asunto, dio la orden de enviar a esos lugares a todos los judíos de Alemania. (Johnson op.cit. 720)

El gueto de Lotz reunía a 200 mil judíos, y la densidad era de 5,8 personas por habitación. Era en sí mismo un centro de exterminio y allí murieron 45 mil personas por enfermedad y hambre. El gueto de Varsovia tenía por lo menos 445 mil judíos, con una densidad por habitación de 7,2 personas; allí, 83 mil individuos murieron de hambre y enfermedad en menos de veinte meses. (Johnson op.cit. 745-746) 
Aunque la cultura judía no depende ni reduce su existencia a sucesos como la Shoah, la diáspora o el guetto, su inclusión y pertenencia son inevitables e indiscutibles. ¿A qué imágenes se vincula el término guetto en Alemania actualmente? «Primero se visualiza una construcción cerrada y amurallada para personas de origen judío, también se piensa en la Segunda Guerra Mundial y en el Nacionalsocialismo, ${ }^{10} \mathrm{y}$ en un segundo momento, el término se concretiza en el guetto de Varsovia». ${ }^{11}$ Este fue el mayor lugar de acogida para judíos alemanes y polacos instaurado por el Nazismo ${ }^{12}$. Una gran visibilidad pública adquirió el guetto de Varsovia con la realización de la película Der Pianist (El pianista), (2002) de Roman Polanski, Lauf Junge Lauf (Corre, chico, corre) (2013) de Pepe Danquart, Geheimsache Ghettofilm (Gueto. La película perdida de la propaganda nazi) ${ }^{13}$ (2010) de Yael Hersonski.

\section{Los trenes}

Otro de los motivos que aparecen en la novela y que se conectan con el genocidio judío es la figura del tren. La situación narrada en la novela, que se limita a un breve suceso, anuncia desde una especie de sueño-pesadilla el destino de millones de judíos que el protagonista anticipa. David sueña, por decirlo de algún modo, el futuro:

El tren se detuvo en la mitad de la noche. Detrás de las ventanillas, en la oscuridad, surgieron luces que oscilaban, nerviosas, a un costado de los rieles. (...) David Burtfichtz se despertó en un pueblo de Polonia, en un puesto de frontera y esperó que llegaran los guardias. (HA 145-146)

David se despierta "en un pueblo de Polonia» que propone el confinamiento en los guettos y recuerda un pasado concentracionario. El puesto de frontera y los guardias, símbolos del control obsesivo y la rigurosidad con que funcionaba el sistema nazi, marcan un destino preciso y final que adelanta los sucesos del Holocausto. David «vive» en su sueño el futuro de los prisioneros, los verdaderos protagonistas, porque él también estaba allí «esper(ando) que llegaran los guardias» para «seleccionarlo» y conducirlo a los campos. Recordemos que en la dictadura nazi, la deportación y posterior concentración de judíos en los campos de trabajo y exterminio se realizaba por ferrocarril (trenes y vagones de mercancía) cuya intervención fue decisiva para la concreción de tal objetivo. ${ }^{14}$ La literatura concentracionaria recoge muchos testimonios y relatos acerca de las deportaciones en tren. Un testimonio de vida lo presta Jorge Semprún, intelectual español y sobreviviente del campo de concentración de Buchenwald. En El largo viaje (1963) relata, desde un texto narrado sin angustias ni detalles superfluos, el trayecto en tren hasta el campo de Buchenwald, donde el narrador y el protagonista son idénticos. Diversas películas, monumentos, muestras fotográficas, objetos de creación, lugares conmemorativos y diarios personales testimonian el trayecto en los trenes rumbo a diferentes destinos. Sobre su uso estratégico y exclusivo para el transporte de millones judíos, fueron filmadas películas y documentales de las cuales quisiéramos destacar solo las que acuden a la figura del tren como símbolo y representación de la muerte. El documental Shoah (1985) del director francés 
Claude Lanzmann es considerada la realización más importante del Holocausto. Aquí el transporte en tren tiene un papel dominante y protagonista. Con nueve horas y medias de duración, Shoah se acerca al pasado mediante la participación de testimonios de sobrevivientes y testigos y la poderosa figura del tren negro, acechante y en permanente movimiento, encarna la idea de irrepresentabilidad del Holocausto. Otra de las películas es Der verlorene Zug: Auf den Rädern der Reichsbahn durch die Hölle (El tren sin rumbo: sobre las ruedas de los ferrocarriles alemanes hacia el infierno) (1999) de Hans-Jürgen-Hermel que tematiza el viaje sin rumbo de un tren (en realidad eran tres vagones) proveniente del campo de Bergen-Belsen que transportaba prisioneros (niños, mujeres y hombres) judíos enfermos y hambrientos. Después de 14 días fueron encontrados por las tropas soviéticas en Tröbitz un estado de higiene y de salud que superaba toda imaginación. Räder müssen rollen. Fahrplanmäßig in den Tod (Las ruedas tienen que seguir rodando. Sin retraso hacia la muerte (1994) del director Pim Richter, testimonia la complicidad del ferrocarril alemán en el proyecto de destrucción nazi. Una gran cantidad de monumentos y exposiciones ${ }^{15}$ recuerdan a las víctimas y a la decisiva participación de la empresa de ferrocarriles alemanes, la por entonces Deutsche Reichsbahn, antecesora de la actual Deutsche Bahn, que en el año 2008 se negó a patrocinar y dar el apoyo a la exposición Der Zug der Erinnerung (El tren del recuer$d o$ ), que tematizaba el papel desempeñado por los trenes en la deportación de niños judíos en el Nacionalsocialismo. Después de 1945 no hubo una reestructuración, cambio de personal, asunción de responsabilidad ni reconocimiento por parte de los ferrocarriles en cuanto a su rol en el transporte de miles de personas hacia los campos de exterminio, ${ }^{16} \mathrm{y}$ su «valiosa» colaboración en el Nacionalsocialismo no trajo ningún tipo de consecuencias negativas para la empresa.

\section{Los aviones}

La ficción ofrece, como hemos visto, un variado repertorio de motivos que conectan el genocidio judío y la Dictadura argentina. Aquí se puede incluir el caso de los aviones y helicópteros de las Fuerzas Armadas cuyo procedimiento y empleo para la eliminación de prisioneros, está estrechamente vinculado al transporte en tren utilizado durante el período Nazi en cuanto a que ambos conducían a los presos a su destino final.

Por aquel tiempo las ensońaciones de las muchachas judías del Once y Paternal (...) producían extraños espejismos: hubo quien vio (...) a las novias de Marc Chagall, (...); otro, nacionalista y supersticioso, creyó que la Cruz del Sur se transformaba en la estrella de David (...). En el Centro Naval, jóvenes de buenas familias (...), pidieron armas para defenderse de los judíos. (...). Nadie hablaba de eso en Buenos Aires, pero El Oriental, en una confidencia con el sainetero, anticipó un baño de sangre en la Argentina. «¿Cuándo?» "Dentro de poco, compañero". Sin embargo, como explicó El Oriental, aquel sería solo un anticipo de otras desgracias, mucho más sangrientas, que, según los pronósticos del payador, alcanzarían su punto más alto desde el otońo de 1976 hasta... — «El Plata se vestirá de duelo» —, pronosticó el payador que veía en el sueño cadáveres de uruguayos y argentinos en cementerios de algas, mujeres encadenadas pudriéndose entre el fango y el liquen. (HA 287-288) 
Las imágenes que aparecen en la cita proponen importantes referentes de la cultura y de la historia judía (el Once, Marc Chagall, estrella de David). Un clima muy raro, mezcla de sueño, fantasía y realidad anuncia una violencia inminente pero contenida que todos presienten, pero que nadie se atreve a pronunciar: «nadie hablaba de eso en Buenos Aires». La existencia de los campos de concentración y las desapariciones en la dictadura fueron ignorados y callados por muchos ciudadanos argentinos que prefirieron negar la realidad del proceso. Otros pagaron la verdad con la vida. Pero pocos o "nadie hablaba de eso en Buenos Aires», dice el narrador-testigo, expresando su preocupación ante la voluntad general de mantenerse al margen de los secretos públicos como fueron los «vuelos de la muerte». ${ }^{17}$ Sin embargo El Oriental se implica «hablando» de lo que ve en sus sueńos para el futuro. «El Plata se vestirá de duelo», dice, pronosticando la desaparición de personas en aquel umbral del Atlántico. Entre los años 1976 y 1980 los ríos Paraná, el delta del Paraná, el Río de la Plata y el Océano Atlántico se transformaron en los«lugares perfectos» para ocultar los cuerpos de los detenidos. Desde los aviones y helicópteros eran arrojadas las víctimas desde el aire, transformando la zona mencionada en grandes cementerios acuáticos.

El sentido tradicional del Río de la Plata como fuente de vida hoy se reduplica en el hecho de que ese río fue la tumba de cientos de desaparecidos y sus aguas espesas y opacas se convirtieron en el símbolo de la imposibilidad de recuperar esos cuerpos torturados que, arrojados desde aviones, terminaron en el mar. (Huyssen, 2000:26)

La desaparición de personas con vida mediante el lanzamiento desde helicópteros en vuelo es una de las formas más silenciosas de borrar las huellas de los crímenes. Por aquellos años «cadáveres de uruguayos y argentinos (...) mujeres encadenadas pudriéndose entre el fango y el liquen» fueron encontrados por los isleños en las costas, en medio de los ríos o en los pantanos, cumpliendo la consigna de atestiguar sin palabras los crímenes, transgrediendo la consigna del olvido. Los aviones que ejecutaban las órdenes de la Junta Militar tirando los cuerpos al agua al igual que los trenes que transportaban presos hacia los campos de concentración fueron los medios y métodos utilizados para la desaparición y la invisibilidad de las víctimas. Instrumentos eficaces y herméticos, estos monstruos de hierro se hacen invisibles en pleno trayecto borrando sus propias huellas apenas se alejan.

La investigación de periodistas ${ }^{18}$ y el compromiso de grupos de derechos humanos que piden el esclarecimiento de los crímenes de lesa humanidad realizados en la dictadura abrieron el camino hacia el enjuiciamiento de los responsables aportando pruebas y testigos cuya causa y condena recién ha comenzado.

\section{El antisemitismo}

En esa compleja red ficcional formada por personajes y una numerosa serie de sucesos aparecen motivos, imágenes y consignas que se conectan y relatan la memoria del antisemitismo en Argentina y la memoria de la muerte en la Alemania nazi. Una vez más David Burtfichtz es el protagonista de un suceso que supera las fronteras nacionales o individuales. Una pintada 
en la fachada de su librería desestabiliza y socava la sensación de seguridad que parecía ofrecer Buenos Aires hasta ese momento:

\section{HAGA PATRIA. MATE A UN JUDÍO}

Pintaron los jóvenes en el muro. Después subieron al auto y dispararon varios tiros al aire. Fue una extraña señal, que tal vez apareció años después o antes, (...); una extraña señal (apareció antes o después de esa mañana en que el señor Burtfichtz abrió las persianas de la librería). (...). Pero alguien (antes o después) escribió la consigna infamante, muchachos farristas que disparaban sus 38 y la Smith Wetson a las tiniebas para asustar a los judíos (...). El señor Burtfichtz abrió la librería, vio la señal pero en verdad no se sorprendió. (HA 173)

La pintada antisemita en la librería de David evoca los hechos de la Semana Trágica de 1919 y al mismo tiempo revive en la memoria de su protagonista, viejos pogromes padecidos en el Imperio Ruso. Pero también acude a «una extrańa señal» o aviso para anunciar lo que sucederá en el futuro contra los negocios judíos en el nazismo. La indeterminación temporal implícita en «años después o antes» y «antes o después» señala la falta de una temporalidad fija y por ende la posibilidad de repetición de los sucesos.

Abrió la persiana del negocio y dio gracias a Dios por estar vivo. (...) Unos vidrios rotos, unas feroces inscripciones, eran todo lo que quedaba de la noche (...). Temeroso, el tendero de la vereda de enfrente, dejó la persiana a medio abrir. (HA 211)

El pogrom del año 1919 habla del brote antisemita en Argentina y simultáneamente rescata de la memoria histórica el plan de destrucción nazi contra las mercancías y los negocios de propietarios judíos, que comenzaría a principios de abril de 1933 en Alemania denominado «El boicot de abril» (Aprilboykott).

La experiencia de David moviliza en el lector los lugares de la memoria de un pasado, configurado mediante fotografías y documentos de negocios clausurados junto a soldados de la SS, vidrieras rotas y pintadas antisemitas con las que dieron comienzo las acciones sistemáticas de destrucción. Estos hechos fueron comparables con pequeños progromes y prepararon el clima social para la instauración del Nacionalsocialismo ${ }^{19}$ que más tarde culminaría con el plan de exterminio masivo y organizado en los campos.

Relacionado al antisemitismo, sus razones y consecuencias en Alemania, quisiéramos referirnos brevemente a un libro publicado en el ańo 2011 por el investigador alemán Götz Aly, donde explica el origen de la violencia ejercida contra la población judía en el Nacionalsocialismo. Warum die Deutschen? Warum die Juden? Gleichheit, Neid und Rassenhass 1800-1933 (¿Por qué los alemanes? ¿Por qué los judios? Igualdad, envidia y odio racial 1800-1933) ${ }^{20}$ aborda la «madre de todas las preguntas»: ${ }^{21}$ por qué los alemanes asesinaron a los judíos y las razones que condujeron al Holocausto. El autor sostiene que, más allá del antisemitismo arraigado por aquel entonces en la sociedad alemana, uno de los ejes y motivadores fundamentales del genocidio fue la envidia material profesada por la población no judía, es decir, católicos y protestantes hacia esta comunidad. A la prosperidad, curiosidad, dinamismo y emprendimiento judío (Aly, 2011:94) el autor agrega la mayor cultura y flexibilidad para el aprendizaje (37-38) en comparación con la falta de dinamismo, flexibilidad y talento de los alemanes (39-48). Otro de los 
factores que contempla es el rencor de la sociedad alemana hacia los grupos exitosos y destacados, y los «sentimientos de inferioridad, sobre todo de los pobladores del campo, muchos de ellos católicos, hacia la burguesía, a la que pertenecían los judíos alemanes en forma numéricamente sobreporcional $»^{22}$ (98). «La prosperidad económica de los judíos fue la razón fundamental para que el odio se popularizara en la mayoría de la población» ("Der wirtschaftliche Aufschwung der Juden wurde der eigentliche Grund dafür, dass der Judenhass in den breiten Massen volkstümlich wurde») (95). Aly destaca que el antisemitismo político no hubiera sido posible sin la participación del factor económico. Como puede observarse, la idea del trabajo pone la cuestión económica como articuladora y desencadenante en la historia del Holocausto.

Volviendo al análisis del contexto histórico de la Semana Trágica, las razones causantes del pogrom en Argentina pueden atribuirse al descontento social general de la sociedad argentina y el miedo al comunismo (impropiamente denominado «maximalismo») de los grupos nacionalistas con el que identificaban a los migrantes judío-rusos. A ésto se debe agregar la existencia de un «antisemitismo popular» ${ }^{23}$ que más tarde se transformó en antisemitismo ${ }^{24}$ étnico.

En Pura memoria, tercera novela de la Trilogía, que tematiza el proceso de cambios políticos y sociales ocurridos a partir de finales del siglo XIX hasta mediados del siglo XX, encontramos un escalamiento de la situación anterior:

Les han pintado una cruz swástica en la pared del frente y el sastre salió a limpiarla, junto a su mujer (...) David piensa que aunque pasen los siglos, siempre habrá un judío inclinado sobre los paños (...) y siempre habrá una guerra y los judíos tendrán que abandonar sus casas y vagar por los campos. (PM 78)

Sin embargo, una especial dimensión de la dictadura argentina conforma su antisemitismo que se traduce en la violencia ejercida contra los secuestrados judíos o de ascendencia judía, cuyo informe le dedica la $\mathrm{CONADEP}^{25}$ una sección especial. En cuanto a la presencia del antisemitismo en Argentina el informe ${ }^{26} \mathrm{de}$ la DAIA del año 2014 registra un aumento del $49 \%$ de denuncias de expresiones o comentarios antisemitas en el ámbito virtual.

Según un $47 \%$ de las denuncias, Internet se constituyó como el ámbito en donde se desarrollaron la mayor cantidad de hechos antisemitas, notándose en este aspecto y con relación a ańos anteriores, un importante descenso del ámbito público (19\%) como escenario de discursos y actos discriminatorios. (DAIA, 2014:25)

En Alemanialas cifras también crecen año a año. ${ }^{27}$ En este espacio el antisemitismo se expresa mediante signos y manifestaciones en forma abierta y directa en el ámbito público (pintadas, insultos, acciones organizadas, demostraciones) y en forma encubierta o indirecta mediante comentarios que relativizan la Shoah, argumentando e igualando el genocidio al conflicto israelí-palestino mediante su banalización, o quejándose por la continua tematización del Holocausto. ${ }^{28} \mathrm{El}$ crecimiento de manifestaciones antijudías en Alemania requiere mayor control y seguridad policial en instituciones y acciones públicas. 


\section{Encuentro(s): una experiencia personal}

Visitar el campo de concentración de Dachau situado a pocos kilómetros de la ciudad de Munich y a unas 3,5 horas del lugar donde vivo, fue algo que quedará para siempre en mi memoria. La experiencia allí vivida junto a mis hijos, por entonces 12 y 13 ańos, y un encuentro muy particular sucedido a nuestro regreso, serán dos circunstancias que configurarán mi visión personal sobre los acontecimientos.

Habíamos proyectado visitar el campo de Dachau y terminar nuestro recorrido en algún museo en Munich, intensión que no pudo concretarse en su totalidad. Una vez en Dachau nos recibió la impresionante inscripción de la puerta de entrada con el conocido lema de algunos campos: «Arbeit macht frei» ${ }^{29}$ (el trabajo libera) que marcaba en pocas palabras una línea de ingreso a otra dimensión. Luego comenzamos a caminar por toda el área recorriendo sus barracas, los dormitorios, el edificio con los hornos crematorios, la cámara de gas, las celdas, los monumentos, las fosas comunes. Vimos sus cercas de alambres y sus torres de control, las casas vecinas pegadas al campo que, imaginamos los tres, no podían evitar ver aquel horror diariamente desde sus ventanas. En nuestro recorrido, sentimos el silencio respetuoso de la mayoría de los visitantes ante tal atrocidad. Después de muchas horas de tensión, tristeza, asombro y espanto, salimos del lugar desorientados y con una sensación física y emocional muy difícil de describir porque ninguno de los tres decía nada. No nos quedaron palabras porque no nos alcanzaban las palabras, por lo que decidimos no hacer escala en Munich. Ya de regreso a nuestra casa, encontré a mi vecino y le expresé mi consternación sobre lo visto. Sin ningún tipo de comentario vomitó un cortante "Ja, Ja» (Sí, sí), inquiriendo: «¿Pero si en la Dictadura militar argentina mataron a 30 mil personas?». Apenas pude reaccionar, apenas pude salir del estado de shock y malestar anímico en que me hallaba. Otros elementos se agregaban ahora. Creo que le hablé de la sistematización de la muerte, del asesinato de 6 millones de judíos, del Holocausto como algo inédito en la historia de la humanidad, de otras muchas razones que convierten al $\mathrm{Na}$ zismo en algo inigualable por su monstruosidad. Creo que él me contestaba con otros «Ja, Ja» porque el tema no le interesaba escuchar ni discutir. A pesar de mis argumentos todavía hoy siento una sensación de impotencia, aturdimiento y de que mi reacción no fue la correcta o la suficiente. El «pero si» minimizaba en dos simples vocablos, la magnitud y el impacto del Holocausto reduciéndolo a algo menor por comparación con otro hecho atroz.

Más allá de este "encuentro", podemos decir que después de 70 años que nos separa del fin de la Segunda Guerra Mundial, la sociedad alemana sigue replanteándose, reflexionando e investigando sobre el Holocausto mediante obras de arte, encuentros internacionales ${ }^{30}$, publicaciones de textos científicos, caricaturas ${ }^{31}$ (algunas de ellas muy provocativas) y películas. Berlín, por ejemplo, con su clima propicio para la creación y el intercambio, se ha transformado en un importantísimo centro de actividades culturales de artistas israelíes, muchas veces descendientes de judíos alemanes emigrados o asesinados. Junto al trabajo desde el plano político y diplomático, los proyectos bilaterales de jóvenes artistas ${ }^{32}$ intentan, a pesar de la casi inexistente población judía en Alemania, la renovación y reactivación desinhibida de un espacio común. 


\section{Notas}

${ }^{1}$ Alguno de los trabajos que quisiera destacar son de: Vidal, Mario: ¡Heil Edén! La conexión argentina con la Alemania Nazi. Buenos Aires: Dunken, 2015; Wang, Diana: Die versteckten Kinder. Aus dem Holocaust nach Buenos Aires. Berlin: Heinrich \& Heinrich, 2012; Villani, Mario: «Nazismo y antisemitismo en los campos de concentración de la Argentina», en: Bericht für das israelische Justizministerium und für den Richter Baltazar Garzón presentado en Madrid (España). Abril 1999; Milgram, Avraham: Entre la aceptación y el rechazo. América Latina y los refugiados judios del nazismo. Jerusalém: Yad Vashem, 2003.

${ }^{2}$ Amalia Ran en su trabajo Nuestra Shoá: Dictaduras, Holocausto y represión en tres novelas judeorioplatenses analiza las obras de tres escritores argentinos donde «La memoria de la Shoá y el discurso del Holocausto sirven (...) para marcar un momento culminante en la reescritura de la historia nacional», en: Ran, Amalia (2009): op.cit. http://digitalcommons.unl. edu/cgi/viewcontent.cgi?article=1048\&context=modlangspanish, pág. 18 ${ }^{3}$ Filmaciones que tematizan el Nazismo y la Dictadura argentina, de: Kanonovich, Bernardo: Aquellos niños (2004), basado en el libro de Diana Wang; Ramos, Víctor: Recuerdos de la sombra, (2009); Bechis, Marco: El rumor de la memoria (2015).

${ }^{4}$ Este vínculo puede observarse en las obras de Manuela Fingueret, Hija del silencio (1999), Liliana Hecker, El fin de la historia, Mauricio Rosencof, Las cartas que no llegaron (2000) y de Marta Oliveri, Memorias del ángel caído (1995).

${ }^{5}$ El título de las tres novelas se abreviarán, respectivamente: AM, HA y PM.

${ }^{6}$ Gewalterfahrung und Utopie. Juden in der europäischen Moderne. Frankfurt a.M.: Fischer Verlag, 1999.

${ }^{7}$ Sobre la vida de los sobrevivientes de Żarki, un shtetl judío-polaco ubicado en la región de Silesia en Polonia, puede consultarse el libro de Wioletta Weiss: Wir sind nur noch wenige. Erinnerungen aus einem Schtetl. Eva: Berlin, 2001.

${ }^{8}$ Loïc Wacquant utiliza estos términos.

${ }^{9}$ Los judíos de diferentes regiones de Europa se orientaron de la siguiente forma: " (...) , los europeos-orientales prefirieron al comienzo la zona céntrica, en los alrededores del templo de la calle Libertad (...) y más tarde otros barrios como Once o Villa Crespo. Los marroquíes o de habla hispana eligieron el barrio Sur, con centro en Constitución. Los judíos sirios de Damasco se instalaron en Boca y Barracas (...). Los que venían de Aleppo, en cambio (...) prefirieron estar en Once, junto a los judíos de Rusia y Polonia. Los sefardíes que hablaban ladino, finalmente, estuvieron en el centro y Villa Crespo en una primera etapa y luego se trasladaron a Colegiales, Flores y Villa Urquiza. (Mirelman 1988, citado por Feierstein, 2007: 195)

${ }^{10}$ Las imágenes que se asocian al término guetto surgen de una pequeńa encuesta realizada con un grupo de adolescentes de 16 y 17 años que trataron tangencialmente el tema en la clase de historia de una escuela secundaria. ${ }^{11}$ El escritor polaco Czeslaw Milosz fue uno de los primeros creadores que inmortalizaron y revivieron la memoria del guetto de Varsovia por 
medio del poema "Campo di Fiori» (1943), donde hace un paralelismo entre la muerte en la hoguera del pensador italiano Giordano Bruno por la Inquisición (1600), con el guetto de Varsovia en llamas, después del levantamiento, como símbolo de la indiferencia de la población y la soledad de las víctimas. Otro poema "Cristiano pobre contempla el guetto» (1945) tematiza la culpa y la actitud de la sociedad ante la destrucción del pueblo judío. Sobre el escritor y su obra puede consultarse, Kowitz-Harms, Stephanie: Die Schoah im Spiegel öffentlicher Konflikte in Polen: Zwischen Opfermythos und Schuldfrage (1985-2001). De Gruyter, Berlin, 2014.

${ }^{12}$ «Los nazis decidieron destruir el gueto el 19 de abril de 1943, utilizando las Waffen-SS. Por entonces sólo quedaban en él 60 mil judíos» (de los 445 mil iniciales) (Johnson, 749).

${ }^{13}$ Sobre la película puede leerse el análisis de: Dimópulos, Mariana: "Verás que todo es mentira», en: http://www.pagina12.com.ar/diario/ suplementos/radar/9-9054-2005-05-07.html (consultado 06.06.16)

${ }^{14}$ Para un informe bastante completo acerca del funcionamiento y organización del sistema ferroviario en el Nacionalsocialismo puede consultarse en idioma español: Historia Virtual del Holocausto. El genocidio nazi cometido contra la población judía entre 1933 y 1945. Los transportes hacia la muerte, en: http://www.elHolocausto.net/parte03/0311.htm (consultado 06/06/16).

${ }^{15}$ La exposición Zug der Erinnerung (Tren del recuerdo) es una «exposición sobre ruedas" que pudo verse en diversas estaciones de trenes, sobre los andenes, y sobre los mismos vagones del Tren del recuerdo, en Alemania y Polonia desde el año 2007 hasta 2013. Tenía como objetivo recordar las deportaciones en masa de miles de niños judíos hacia los campos de concentración y de exterminio.

${ }^{16}$ Un informe detallado sobre la historia en la que se basa la película Räder müssen rollen, Fahrplanmäßig in den Tod puede leerse en: «Allgemeine Informationen zu Deportationen der Reichsbahn», en: http://www.openmemory.info/deportation-deutschebahn.php (consultado 06/06/16).

${ }^{17}$ La primera publicación sobre los vuelos de la muerte fue realizada por el periodista Horacio Verbitsky en 1995 con el título de El Vuelo. Buenos Aires: Planeta. Fabián Magnotta, otro periodista, es el autor de El lugar perfecto. Dictadura: vuelos de la muerte y desaparecidos en el delta entrerriano (1976-1980), donde investiga los vuelos en la dictadura militar. ${ }^{18}$ Sobre el tema puede leerse una nota del diario Página12 http://www. pagina12.com.ar/diario/elpais/1-258680-2014-10-30.html (consultado 06/07/16).

${ }^{19}$ Las actividades públicas de Hitler dieron comienzo en 1920, época muy cercana a los sucesos acontecidos en Buenos Aires, cuyo episodio no puede verse de forma aislada sino como un hecho que acompaña temporalmente el crecimiento del antisemitismo en Europa.

${ }^{20}$ La traducción del título de la obra de Götz Aly que aparece entre paréntesis, es mía. La traducción en español lleva el título de: ¿Por qué los alemanes? ¿Por qué los judios? Las causas del Holocausto. Traducción de Héctor Piquer Minguijón, Crítica, Barcelona, 2015.

${ }^{21}$ Un comentario breve del trabajo puede leerse en: http://www.elcultural. 
com/revista/letras/Por-que-los-alemanes-Por-que-los-judios/32232 (consultado 01/06/16).

${ }^{22} \mathrm{La}$ frase es una traducción casi textual del libro.

${ }^{23}$ Avni, 1995:200.

${ }^{24}$ «En la década de 1920 el antisemitismo comenzó a manifestarse en todas las organizaciones y publicaciones nacionalistas. La Nueva República, fundada en 1927, y la Liga Republicana, organizada en 1929, estuvieron influenciadas por el ideólogo fascista francés Charles Maurras, fueron los precursores de organizaciones más grandes forjadas en los años treinta. (...) Aun antes del ascenso de Hitler al poder (el periódico La Bandera Argentina, 1932), publicó fragmentos de Mein Kampf y proclamó la necesidad de salvar la cultura occidenal de la "plaga eslavo-semítica" ", en: Avni, 1995:201.

${ }^{25}$ Comisión Nacional sobre la Desaparición de Personas (CONADEP), Nunca Más, Buenos Aires, Editorial Universitaria de Buenos Aires, 1985, 69-75.

${ }^{26}$ Sobre el antisemitismo en Argentina en el año 2014 puede consultarse: «Informe sobre antisemitismo en la Argentina 2014». Marisa Braylan (comp.). CES. Centro de Estudios Sociales. DAIA Delegación de Asociaciones Israelitas Argentina: http://www.daia.org.ar/2013/uploads/ documentos/109/informe\%20antisemitismo\%202015\%20(2014)\%20 CORREGIDO.pdf (consultado 15.06.16).

${ }^{27}$ Datos recientes acerca del antisemitismo y el potencial antidemocrático de la sociedad alemana, pueden consultarse en dos estudios. El primero se denomina «Die enthemmte Mitte. Autoritäre und Rechtsextreme Einstellung in Deutschland». Die Leipziger Mitte-Studie 2016 ( «La deshinibición del centro. Posiciones/actitudes autoritarias y de extrema derecha en Alemania») realizado en 2016 por la Universidad de Leipzig en cooperación con las Fundaciones Heinrich-Böll, Otto-Brenner y RosaLuxemburg, en: https://www.boell.de/sites/default/files/2016-06-mitte_studie_uni_leipzig.pdf. El segundo es un artículo publicado en 2007 por la Bundeszentrale für politische Bildung (BPB) (Central nacional para la formación política) denominado «Antisemitismus in Deutschland und Europa» («Antisemitismo en Alemania y Europa»), en: http://www. bpb.de/apuz/30329/antisemitismus-in-deutschland-und-europa (artículos consultados 15/06/16). Sobre el antisemitismo en Alemania puede consultarse: «Informe sobre antisemitismo en la Argentina 2014». Marisa Braylan (comp.). CES. Centro de Estudios Sociales. DAIA Delegación de Asociaciones Israelitas Argentina, 69-70. http://www.daia.org.ar/2013/ uploads/documentos/109/informe\%20antisemitismo\%202015\%20 (2014)\%20CORREGIDO.pdf (consultado 15.06.16).

${ }^{28}$ Los ejemplos fueron tomados del artículo Antisemitismo en Alemania y Europa, op. cit. 2.

${ }^{29} \mathrm{El}$ cartel con la inscripción fue robado del campo el 2 de noviembre de 2014.

${ }^{30} \mathrm{~A}$ la sombra de la historia y en un lugar muy controvertido, se festejaron en julio de 2015 en Berlín las competiciones deportivas judías más grandes de Europa, la European Maccabi Games, una especie de Juegos 
olímpicos judíos. En el mismo lugar donde Hitler organizó las Olimpíadas del año 1936, es decir, 70 años después de la Shoah. Con más de 100 mil turistas israelíes por año, Berlín es una de las capitales preferidas. ${ }^{31}$ El artista israelí Erez Isreali presentó en Berlín una muestra de ilustraciones con juegos de palabras, doble sentido y mucho de humor negro sobre el Holocausto. Algunas ilustraciones pueden verse en la revista Zeit Magazin, (20), 13 de mayo de 2015, 40-48.

${ }^{32}$ Como uno de los eventos comunes más tradicionales puede citarse el Festival de Cine Judío de Berlin y Brandenburgo (JFBB) que se realiza desde hace 22 años.

\section{Referencias bibliográficas}

Aly, G. (2011). Warum die Deutschen? Warum die Juden? Gleichheit, Neid und Rassenhass 1800-1933. Frankfurt a.M: Fischer.

Avni, Haim (1995). El antisemitismo en Argentina: las dimensiones del peligro. En: Senkman, L. En Sznajder, M. (Comp.), El legado del autoritarismo. Derechos humanos y antisemitismo en la Argentina contemporánea (pp. 197-216). Buenos Aires: Grupo Editor Latinoamericano. Benmergui, A. (2004). Alberto Gerchunoff y Pedro Wald: dos visiones contrapuestas acerca de dos momentos de la historia argentina. En Feierstein, R. y Sadow, S. (Comp.), Recreando la Cultura judeoargentina/2. Literatura y Artes Plásticas, Tomo 1 (pp. 122-130). Buenos Aires: Milá. BraH, A. (2011). Cartografias de la diáspora. Identidades en cuestión (Traduccción de Sergio Ojeda). Madrid: Traficantes de sueños. Cohen, R. (1997). Global diasporas. An introduction. London: UCL Press. DAIA (2014). Informe sobre antisemitismo en la Argentina 2014. En Marisa Braylan (Comp.), CES. Centro de Estudios Sociales. DAIA Delegación de Asociaciones Israelitas Argentina [en línea]. Consultado 15 de junio de 2016 en http://www.daia.org.ar/2013/uploads/ documentos/109/informe\%20antisemitismo\%202015\%20(2014)\%20 CORREGIDO.pdf

Devoto, F. (2003). Historia de la Inmigración en la Argentina. Buenos Aires: Sudamericana.

Feierstein, R. (2007). Vida cotidiana de los judíos argentinos. Del gueto al country. Buenos Aires: Sudamericana.

Fernández Vicente, A. (CoORd.) (2010). Nomadismos contemporáneos: formas tecnoculturales de la globalización. Murcia: Edit.um.

Huyssen, A. (2000). El Parque de la Memoria. Una glosa desde lejos. Punto de Vista. Revista de cultura. XXIII (68), 25-28.

Kaufman, E. (1995). Análisis de los patrones represivos en el Cono Sur: los regímenes militares argentinos (1976-1093). En Senkman, L. y Sznajder, M. (Comps.), El legado del autoritarismo. Derechos humanosy antisemitismo en la Argentina contemporánea (pp. 55-78). Buenos Aires: Grupo Editor Latinoamericano.

KARADY, V. (1999). Gewalterfahrung und Utopie. Juden in der europäischen 


\begin{abstract}
Moderne. Frankfurt a. M.: Fischer Verlag.
KARDUNER, L. (1934). Misión del escritor judío en la literatura argentina.

Judaica II (16), 145-149.

LerNer, N. (1989). Las raíces ideológicas del antisemitimso en la Argentina y el nacionalismo. En Senkman, L. (Comp.), El antisemitismo en la Argentina (pp. 195-234). Buenos Aires: Centro Editor de América Latina. MaYer, R. (2005). Diaspora. Eine kritische Begriffsbestimmung. Bielefeld: Transcript Verlag.

WaCQuANT, L. (2010). Las dos caras de un gueto. Ensayos sobre marginalización y penalización. Buenos Aires: Siglo Veintiuno.

WeIss, W. (2001). Wir sind nur noch wenige. Erinnerungen aus einem Schtetl. Berlin: Eva.
\end{abstract}

\title{
Zehnder, Sabrina
}

